\title{
Benefits of ginger in the control of chemotherapy-induced nausea and vomiting
}

\author{
Benefícios do gengibre no controle da náusea e vômito induzidos pela quimioterapia \\ Beneficios del jengibre en el control de náusea y vómito inducidos por la quimioterapia
}

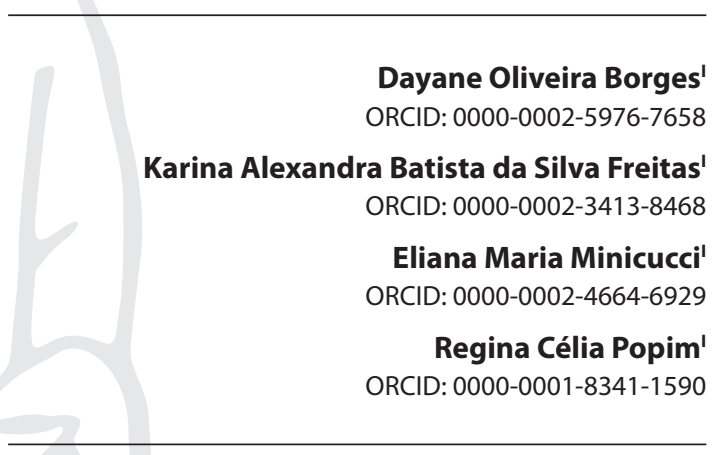

'Universidade Estadual Paulista. Botucatu,São Paulo, Brazil.

How to cite this article: Borges DO, Freitas KABS, Minicucci EM, Popim RC. Benefits of ginger in the control of chemotherapy-induced nausea and vomiting. Rev Bras Enferm. 2020;73(2):e20180903. doi: http://dx.doi.org/10.1590/0034-7167-2018-0903

Corresponding Author:

Dayane Oliveira Borges

E-mail: d.oliveiraborges@yahoo.com.br

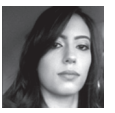

EDITOR IN CHIEF: Dulce Aparecida Barbosa ASSOCIATE EDITOR: Mitzy Danski

Submission: 11-19-2018

Approval: 12-19-2019

\begin{abstract}
Objectives: To identify and discuss scientific evidence of the effects of ginger use on the management of chemotherapy-induced nausea and vomiting. Methods: This is an integrative review performed by Ganong's reference. Results: We included 24 studies, highlighting three thematic categories, namely 1 ) antiemetic action of ginger - nausea (13 articles; of these, nine significant) and emesis (10 studies; of these, six significant); 2 ) action in the control of nausea (11 articles; of these, six significant) and vomiting (8 articles; of these, three significant) in the acute phase; 3 ) action in the control of nausea ( 6 articles; of these, three significant) and vomiting ( 6 articles; of these, three significant) in the delayed phase. There were divergences of the methods used. Final considerations: This complementary therapy has low cost and easy access, but no statistical confirmation of its effectiveness in the management of nausea and vomiting in cancer patients was found.

Descriptors: Nausea; Vomiting; Chemotherapy; Ginger; Zingiber Officinale.
\end{abstract}

\section{RESUMO}

Objetivos: Identificar e discutir evidências científicas dos efeitos do uso do gengibre no manejo da náusea e vômito induzidos pela quimioterapia. Métodos: Trata-se de revisão integrativa baseada no referencial de Ganong. Resultados: Foram incluídos 24 estudos, destacando-se 3 categorias temáticas, a saber, 1) ação antiemética do gengibre - foi avaliada a náusea (13 artigos; destes, 9 significativos) e êmese (10 estudos; destes, 6 significativos); 2) ação no controle da náusea (11 artigos; destes, 6 significativos) e vômito (8 artigos; destes, 3 significativos) na fase aguda; 3 ) ação no controle da náusea ( 6 artigos; destes, 3 significativos) e vômito ( 6 artigos; destes, 3 significativos) na fase tardia. Houve divergências dos métodos utilizados. Considerações finais: Essa terapia complementar é de baixo custo e fácil acesso, mas não foi encontrada confirmação estatística de sua efetividade no manejo da náusea e vômito em pacientes oncológicos.

Descritores: Náusea; Vômito; Quimioterapia; Gengibre; Zingiber Officinale.

\section{RESUMEN}

Objetivos: Identificar y discutir evidencias científicas de los efectos del uso del jengibre en el manejo de la náusea y vomito inducidos por la quimioterapia. Métodos: Se trata de revisión integrante realizada por el referencial Ganong. Resultados: Han sido incluidos 24 estudios, destacándose 3 categorías temáticas: 1) acción antiemética del jengibre - ha sido evaluada la náusea (13 artículos [9 significativos]) y emesis (10 estudios [6 significativos]); 2) acción en el control de la náusea (11 artículos [6 significativos]) y vomito (8 artículos [3 significativos]) en la fase aguda; 3 ) acción en el control de la náusea (6 artículos [3 significativos]) y vomito (6 artículos [3 significativos]) en la fase tardía. Hubo divergencias de los métodos utilizados. Consideraciones finales: Esa terapia complementar ha sido de bajo costo y fácil acceso, pero no ha sido encontrada confirmación estadística de su efectividad en el manejo de la náusea y vomito en pacientes oncológicos.

Descriptores: Náusea; Vómitos; Quimioterapia; Jengibre; Zingiber Officinale. 


\section{INTRODUCTION}

According to the Instituto Nacional do Câncer (INCA- National Cancer Institute) $)^{(1)}$, around 600,000 new diagnoses of the disease will be made in 2018 and 2019, except for nonmelanoma skin neoplasms, which is expected to present approximately 170,000 new episodes. Thus, a rate of 420,000 new cancers is expected for the period.

The use of nutritional supplementation and plant-derived treatments was frequent among patients with neoplasms ${ }^{(2,3)}$. Approximately $80 \%$ of cancer patients already consume vitamin and mineral supplements, while $14 \%$ to $32 \%$ start using supplements after the diagnosis of neoplasms $s^{(2,4)}$. These complementary therapies may help in the management of adverse effects (such as nausea, emesis, and mucositis) of pathology and treatment ${ }^{(2,5)}$. The area of integrative oncology systematizes the provision of complementary evidence-based treatments associated with traditional neoplasm therapy. These forms of therapy comprise a variety of psychological and physical actions, natural products, and changes in lifestyle ${ }^{(6-8)}$.

Ginger has been used for many years as a drug for gastrointestinal disorders due to its chemical components. Ginger Rhizome has a diversity of bioactive elements, including gingerols, shogaols, zingiberene, zingerone and paradol, which can encourage oral and gastric secretions, normalize gastrointestinal motility, communicate with the $5 \mathrm{HT} 3$ and NK1 receptors related to the nausea reflex and emesis resulting, for example, from chemotherapy treatment, in addition to acting on free radicals. However, it can also cause adverse reactions, such as dermatitis and poor digestion, which can be confused with the permanence of nausea(2).

Some authors have observed that ginger can influence the control of nausea and vomiting induced by chemotherapy, however, divergences in the methodologies employed and contradictory results hinder the convergence of conclusions ${ }^{(2)}$. The different evidence in the literature is also due to the performed evaluation of symptoms at different stages of treatment, including: anticipatory (before chemotherapy), acute (up to 24 hours after administration of antineoplastic agent) and delayed (from 24 hours after administration up to 4 or 5 days later) ${ }^{(9)}$. Given this scenario, we can ask: "What is the effect of ginger on controlling chemotherapy-induced nausea and emesis in chemotherapy patients?"This study proposes to answer this question.

\section{OBJECTIVES}

To identify and discuss published studies that evaluated the effect of ginger consumption on the management of chemotherapy-induced nausea and vomiting.

\section{METHODS}

\section{Ethical aspects}

Ethical and legal aspects were considered, since we used manuscripts published in international journals, and there is a reference to the authors after the citation.

\section{Study Design, location, and period}

This study conducted an integrative review of the literature, that is, an investigation of scientific knowledge already elaborated on an established content. In this perspective, the method allows the synthesis of several published studies, thus providing general conclusions about a field of investigation ${ }^{(10)}$. Ganong ${ }^{(11)}$ was used as a theoretical framework to develop a review strategy. Also, Check List Preferred Items for Systematic Reviews and MetaAnalyses (PRISMA) ${ }^{(12)}$ was used to ensure the quality of this study and detailed textual development and designing the diagram that distinguishes the stages of selection of the included articles (Figure 1). We made the selection of the articles in June and July 2018 in the city of Botucatu, SP, Brazil.


Figure 1 - Selection diagram of the articles included in this integrative review, according to Check List Preferred Items for Systematic Reviews and Meta-Analyses, $2018^{(12)}$

\section{Sample: inclusion and exclusion criteria}

The inclusion criteria consisted of research with the descriptors present in the title or abstract, and that addressed the effect of ginger to control nausea and vomiting in patients undergoing chemotherapy, without delimitation of publication time and restriction of the study method. We excluded investigations that did not have the abstract or full article available, systematic and integrative reviews, studies that were in any language other than English, Portuguese and Spanish, repeated publications, gray literature - which publishes unpublished papers, including congressional summaries and technical documents-, animal research, or that were in progress and did not use the oral administration of ginger.

\section{Study protocol and results analysis}

According to Ganong's theoretical framework ${ }^{(11)}$, we included the following steps: 


\section{1 st. Step: Research question selection}

The recognition of the theme was performed, which comprises the action of ginger to manage nausea and emesis induced by chemotherapy. We considered the four components of the PICO ${ }^{(13)}$ strategy - Patient: those undergoing chemotherapy treatment; Intervention: use of ginger orally; Comparation: groups that did not use ginger or who used placebo; Outcomes: antiemetic action of ginger. Based on this, the research question was developed: "What is the effect of ginger on controlling chemotherapy-induced nausea and emesis in chemotherapy patients?"

The selected search terms and their respective combinations were in English through the MeSH (Medical Subject Headings) Database: chemotherapy OR chemotherapies AND nausea AND vomiting OR emesis AND ginger OR zingiber AND officinale OR zingiber AND officinales. Through the DeCS (Health Sciences Descriptors), the descriptors and combination used were, in Portuguese, chemotherapy AND nausea AND vomiting OR emesis AND Ginger OR Zingiber officinale. The boolean form, AND/OR, was used to help find the studies of the online database.

\section{2nd. Step: Sampling}

We defined the sample in June and July 2018. For the selection of publications, the utilized electronic databases were Emabase, National Library of Medicine and Cochrane Library. In order to maintain the quality of the review method, the selection of studies was made by two evaluators, autonomously and blindly, following the criteria of inclusion and exclusion stipulated. For this, the initial step was to analyze the articles by the title and abstract; in cases in which they did not present sufficient content to define the initial selection, the authors performed the full reading of the investigation, and the solved the divergences when there was an agreement between them. The critical analysis of this sampling is essential to evaluate the internal validity of the review, as it is an indication to prove the reliability, dimension and influence of generalization of the conclusions of the review ${ }^{(11)}$.

\section{3rd. Step: Representation of the characteristics of the research}

To perform the collection, organization, and analysis of the data and synthesis of knowledge, we described the characterization of the investigations after a careful reading of the title, abstract, and article. Thus, after completing this step, a table was elaborated in Excel with the pre-selected studies for the integrative review.

\section{4th. Step: Analysis of selected studies}

To categorize the selected investigations, the researchers used an instrument based on the synthesis matrix to synthesize and integrate the results of the investigations, enabling the isolated evaluation of each article, both at the methodological level regarding the results of the research.

\section{5th. Step: Analysis and interpretation of results}

To summarize the evidence found, we performed readings, categorization, and investigation of the articles related to the proposed objectives, and the data were expressed in tables to aid the interpretation.

\section{6th. Step: Review report:}

From the analysis of the data described in the synthesis matrix, and the tables and graphs generated, the following step was to perform the representative synthesis of the selected articles.

\section{RESULTS}

From the titles and abstracts analyzed, 1,798 articles were in Embase, 3,329 were in the National Library of Medicine, and 188 the Cochrane Library. Of these, 24 studies met the inclusion criteria, and Chart 1 presents the performed full reading and synthesizing of the data.

Chart 1 - Characteristics of the clinical studies selected according to the reference, year/country, design/ number of patients, interventions, and outcomes, São Paulo, Brazil, 2019

\begin{tabular}{|c|c|c|c|c|}
\hline Reference & $\begin{array}{l}\text { Yearl } \\
\text { Country }\end{array}$ & $\begin{array}{l}\text { Design/Number of } \\
\text { patients }\end{array}$ & Interventions & Outcomes \\
\hline $1^{(14)}$ & $\begin{array}{l}2017 / \\
\text { Iran }\end{array}$ & $\begin{array}{l}\text { Randomized } \\
\text { controlled clinical } \\
\text { trial, } n=49 \text { women. }\end{array}$ & $\begin{array}{l}\text { Continuous consumption of } 1 \text { gram } \\
\text { of ginger } 2 \text { times/day, for } 6 \text { cycles, by } \\
\text { patients undergoing platinum treatment } \\
\text { (carboplatin and paclitaxel). }\end{array}$ & $\begin{array}{l}\text { There were no differences between the control group } \\
\text { and the intervention group }(p=0,57) \text {. }\end{array}$ \\
\hline $2^{(15)}$ & 2017/ & $\begin{array}{l}\text { Double-blind, } \\
\text { randomized placebo- } \\
\text { controlled trial, } n= \\
51 \text { ( } 19 \text { men and } 32 \\
\text { women). }\end{array}$ & $\begin{array}{l}\text { A dose of } 1.2 \mathrm{~g} \text { of ginger } 4 \text { times/day, for } 5 \\
\text { days, in } 3 \text { cycles, by chemotherapy patients } \\
\text { with emetogenic potential from moderate } \\
\text { to high. }\end{array}$ & $\begin{array}{l}\text { There was no significant difference between the placebo } \\
\text { group and the intervention group }(p>0.05) \text { concerning } \\
\text { nausea and emesis. There were also no differences between } \\
\text { the groups concerning the use of aprepitant }(p>0,05) \text {. }\end{array}$ \\
\hline $3^{(16)}$ & $\begin{array}{l}\text { 2017/ } \\
\text { Thailand }\end{array}$ & $\begin{array}{l}\text { Double-blind, } \\
\text { randomized placebo- } \\
\text { controlled phase II } \\
\text { study, } \mathrm{n}=96 \text { ( } 21 \text { men } \\
\text { and } 75 \text { women). }\end{array}$ & $\begin{array}{l}\text { Consumption of } 10 \mathrm{~g} \text { of ginger } 2 \text { times/day, } \\
\text { for } 4 \text { days, in } 4 \text { cycles, by chemotherapy } \\
\text { patients with emetogenic potential from } \\
\text { moderate to high. }\end{array}$ & $\begin{array}{l}\text { The emesis was lower in the experimental group ( } p \\
<0.001) \text {, similar to grade } 3 \text { vomiting }(p=0.001) \text {. The } \\
\text { intensity of nausea was lower in the experimental } \\
\text { group (mild, }>17 \% \text {; moderate, }>39 \% \text {; and severe, }> \\
34 \% ; p=0.001) \text {. }\end{array}$ \\
\hline $4^{(17)}$ & $\begin{array}{l}\text { 2016/ } \\
\text { Thailand }\end{array}$ & $\begin{array}{l}\text { Randomized controlled, } \\
\text { double-blind, crossover } \\
\text { study, } \mathrm{n}=34 \text { women. }\end{array}$ & $\begin{array}{l}1 \mathrm{~g} \text { ginger, } 2 \text { times/day, for } 5 \text { days, in } \\
\text { the } 2 \text { nd and } 3 \text { rd cycles, by patients } \\
\text { undergoing treatment with doxorubicin and } \\
\text { cyclophosphamide. }\end{array}$ & $\begin{array}{l}\text { Emesis: } p=0.5 \text {. There was no statistically significant } \\
\text { difference in the use of rescue medication, considering } \\
\text { a significance level of } 5 \% \text {. }\end{array}$ \\
\hline
\end{tabular}


Chart 1

\begin{tabular}{|c|c|c|c|c|}
\hline Reference & $\begin{array}{c}\text { Yearl } \\
\text { Country }\end{array}$ & $\begin{array}{l}\text { Design/Number of } \\
\text { patients }\end{array}$ & Interventions & Outcomes \\
\hline $5^{(18)}$ & $\begin{array}{l}2017 / \\
\text { Italy }\end{array}$ & $\begin{array}{l}\text { Randomized, } \\
\text { double-blind, } \\
\text { placebo-controlled } \\
\text { multicenter study, } \mathrm{n}= \\
244 \text { (160 men and } 84 \\
\text { women). }\end{array}$ & $\begin{array}{l}1 \mathrm{~g} \text { ginger, } 4 \text { times/day, for } 19 \text { or } 27 \text { days } \\
\text { during } 2 \text { cycles by patients undergoing } \\
\text { cisplatin treatment. }\end{array}$ & $\begin{array}{l}\text { In the } 1 \text { st cycle, mean FLIE score on day } 1: p=0.147 \text {. In the } \\
\text { 2nd cycle, mean FLIE score on day } 1: p=0.675 . \text { In the } 1 \text { st } \\
\text { cycle, day } 2: p=0.782 \text {. In the } 2 \text { nd cycle, day } 2: p=0.733 \text {. } \\
\text { In the } 1 \text { st cycle delayed nausea: } p=0.851 \text {. In the } 2^{\text {nd }} \text { cycle } \\
\text { delayed nausea: } p=0.379 \text {. Therefore, both cycles (1st and } \\
\text { 2nd) did not present statistically significant differences } \\
\text { considering significance level of } 5 \% \text {. }\end{array}$ \\
\hline $6^{(19)}$ & $\begin{array}{c}\text { 2016/ } \\
\text { Thailand }\end{array}$ & $\begin{array}{l}\text { Prospective, } \\
\text { randomized, placebo- } \\
\text { controlled study, } \mathrm{n}= \\
150 \text { women. }\end{array}$ & $\begin{array}{l}1 \mathrm{~g} \text { ginger, } 4 \text { times/day, for } 3 \text { days during } 3 \\
\text { cycles by patients undergoing treatment } \\
\text { with Doxorrubicicin/cyclophosphamide; } \\
\text { cyclophosphamide/Doxorrubicicin/5- } \\
\text { Fluorouracil; Docetaxel/ Doxorrubicicin/ } \\
\text { cyclophosphamide. }\end{array}$ & $\begin{array}{l}\text { In the 1st cycle nausea: experimental group (1.36); } \\
\text { control group (1.46) .2nd cycle nausea: experimental } \\
\text { group (1.36); control group (1.32). 3rd cycle nausea: } \\
\text { experimental group (1.42), control group (1.37); } \\
\text { therefore, nausea was higher in the group that used } \\
\text { ginger in the } 2 \text { nd and 3rd cycle. Reduction of emesis in } \\
\text { the experimental group from } 1.4 \text { to } 0.71 .\end{array}$ \\
\hline $7^{(20)}$ & Thailand & $\begin{array}{l}\text { Randomized, double- } \\
\text { blind clinical trial, } \mathrm{n}= \\
65 \text { women. }\end{array}$ & $\begin{array}{l}1 \mathrm{~g} \text { of ginger, } 2 \text { times/day, for } 10 \text { days from } \\
\text { the } 2 \text { nd cycle. }\end{array}$ & $\begin{array}{l}\text { Ginger was not effective for the management of } \\
\text { nausea }(p=0.238) \text {, but it demonstrated benefits in the } \\
\text { incidence of vomiting }(p<0.0001) \text {. }\end{array}$ \\
\hline $8^{(21)}$ & $\begin{array}{l}2015 / \\
\text { Turkey }\end{array}$ & $\begin{array}{l}\text { Randomized } \\
\text { and controlled } \\
\text { experimental study, } \mathrm{n} \\
=60 \text { women. }\end{array}$ & $\begin{array}{l}\text { Ginger consumption for } 3 \text { days, no further } \\
\text { specifications. }\end{array}$ & $\begin{array}{l}\text { The incidence of emesis and intensity of nausea } \\
\text { were lower in the experimental group }(p<0.05) \text {. } \\
\text { Nevertheless, the incidence of nausea did not change } \\
\text { between groups. }\end{array}$ \\
\hline $9^{(22)}$ & Australia & \begin{tabular}{|l|} 
Double-blind, \\
randomized placebo- \\
controlled study, $\mathrm{n}=53$. \\
\end{tabular} & $\begin{array}{l}\text { A dose of } 1.2 \mathrm{~g} \text { of ginger, } 4 \text { times/day, for } \\
5 \text { days, by chemotherapy patients with } \\
\text { emetogenic potential from moderate to high. }\end{array}$ & $\begin{array}{l}\text { There were no significant differences between groups } \\
\text { regarding adverse effects }(p>0.05) \text {. }\end{array}$ \\
\hline $10^{(23)}$ & Thailand & $\begin{array}{l}\text { Randomized, double- } \\
\text { blind, controlled } \\
\text { clinical trial, } n=87 \\
\end{array}$ & $\begin{array}{l}\text { Consumption of } 10 \mathrm{mg} \text { of ginger, } 2 \text { times/day, } \\
\text { for } 4 \text { cycles, by chemotherapy patients with } \\
\text { emetogenic potential from moderate to high. }\end{array}$ & $\begin{array}{l}\text { Significant reduction in the occurrence of acute }(p= \\
0.013) \text { and delayed emesis }(p<0,001) \text {, acute nausea ( } p \\
=0.002) \text { and delayed }(p<0.001)\end{array}$ \\
\hline $11^{(24)}$ & $\begin{array}{l}\text { 2013/ } \\
\text { Iran }\end{array}$ & $\begin{array}{l}\text { Randomized, double- } \\
\text { blind, placebo- } \\
\text { controlled clinical } \\
\text { trial, } \mathrm{n}=80 \text { women. } \\
\end{array}$ & $1 \mathrm{~g}$ of ginger, 4 times / day, for 6 days. & $\begin{array}{l}\text { The incidence and intensity of anticipatory nausea } \\
\text { were significantly lower in the experimental group } \\
(p=0.0008 \text { vs. } p=0.0007 \text { ), as well as in acute nausea } \\
\text { (incidence and intensity } p=0.0001 \text { ). }\end{array}$ \\
\hline $12^{(25)}$ & $\begin{array}{l}\text { 2013/ } \\
\text { Iran }\end{array}$ & $\begin{array}{l}\text { Randomized } \\
\text { crossover clinical trial } \\
\text { (1st cycle, } n=44 ; \text { and } \\
\text { 2nd cycle, } n=31 \text {. }\end{array}$ & $\begin{array}{l}\text { Consumption of } 0.25 \mathrm{~g} \text { of ginger, } 4 \text { times/ } \\
\text { day, for } 2 \text { cycles, by patients undergoing } \\
\text { cisplatin treatment. }\end{array}$ & $\begin{array}{l}\text { In the } 1 \text { st cycle, ginger reduced the intensity of nausea in } \\
\text { the } 1 \text { st hour by } 9 \% \text {; in the } 2 \text { nd hour, by } 18.2 \% \text {; in the } 3 r d \\
\text { hour, by } 13.7 \% \text {; in the } 4 \text { th hour, by } 22.7 \% \text {; and, at the end of } \\
24 \text { hours, by } 27.3 \% \text {. Concerning vomiting, in the } 1 \text { st cycle, } \\
\text { there was a reduction of } 9.1 \% \text { in the } 1 \text { st hour, } 9.1 \% \text { in the } \\
2 \text { nd hour, } 9.1 \% \text { in the } 3 r d \text { hour, } 4.6 \% \text { in the } 4 \text { th hour, and } \\
4.7 \% \text { in the final } 24 \text { hours. In the } 2 \text { nd cycle, the intensity was } \\
\text { lower in the control group. The value of } p \text { in both was }>0.05 \text {. }\end{array}$ \\
\hline $13^{(26)}$ & $\begin{array}{l}\text { 2012/ } \\
\text { Iran }\end{array}$ & $\begin{array}{l}\text { Randomized, open } \\
\text { pilot clinical trial, } n= \\
100 \text { women. }\end{array}$ & $\begin{array}{l}\text { Consumption of } 1.5 \mathrm{~g} \text { of ginger, } 3 \text { times/ } \\
\text { day, for } 4 \text { days, by patients undergoing } \\
\text { treatment with docetaxel, epirubicin, } \\
\text { cyclophosphamide. }\end{array}$ & $\begin{array}{l}\text { Experimental group: a significant decrease in the } \\
\text { incidence of nausea in the period from } 6 \text { to } 24 \text { hours } \\
\text { after chemotherapy }(p=0.04) \text {. In the first } 6 \text { hours, on the } \\
\text { second, third, and fourth day after chemotherapy, there } \\
\text { was no difference between the groups in the incidence } \\
\text { of nausea, emesis }(p>0.05) \text {. }\end{array}$ \\
\hline $14^{(27)}$ & $\begin{array}{l}2012 / \\
\text { United } \\
\text { States }\end{array}$ & $\begin{array}{l}\text { Randomized, double- } \\
\text { blind, placebo- } \\
\text { controlled clinical trial, } \\
\mathrm{n}=576 \text { ( } 55 \text { men and } \\
521 \text { women). }\end{array}$ & $\begin{array}{l}\text { Consumption of } 0.5 \mathrm{~g}, 1 \mathrm{~g} \text { or } 1.5 \mathrm{~g} \text { of ginger } \\
\text { for } 1,2 \text { or } 3 \text { times / day, for } 6 \text { days for } 3 \\
\text { cycles. }\end{array}$ & $\begin{array}{l}\text { Experimental group: reduction of acute nausea }(p= \\
0.013 \text { vs. } 0.003) \text {. There was a reduction in anticipatory } \\
\text { nausea }(p<0.0001) \text {. The incidence of emesis in all } \\
\text { patients was low }(p=0.5) \text {. }\end{array}$ \\
\hline $15^{(28)}$ & $\begin{array}{l}2011 / \\
\text { India }\end{array}$ & $\begin{array}{l}\text { Prospective study, } \mathrm{n}= \\
600 \text { cycles. }\end{array}$ & Consumption of $2 \mathrm{~g}$ of ginger for 3 days. & $\begin{array}{l}\text { All patients used ginger; of these, } 5 \% \text { had moderate to } \\
\text { severe acute nausea, } 5 \% \text { had moderate to severe acute } \\
\text { emesis, } 15 \% \text { had moderate to severe nausea and emesis. }\end{array}$ \\
\hline $16^{(29)}$ & $\begin{array}{l}2011 / \\
\text { India }\end{array}$ & $\begin{array}{l}\text { Prospective, } \\
\text { randomized, double- } \\
\text { blind and randomized } \\
\text { institutional study, } n \\
=60 \text { (40 men and } 20 \\
\text { women). }\end{array}$ & $\begin{array}{l}\text { Consumption of } 1 \text { or } 2 \mathrm{~g} \text { of ginger } \\
\text { according to weight, } 5 \text { or } 6 \text { times/day, for } 3 \\
\text { days up to } 3 \text { cycles, by patients undergoing } \\
\text { cisplatin / doxorubicin treatment. }\end{array}$ & $\begin{array}{l}\text { Moderate to severe acute nausea was lower in the } \\
\text { experimental group }(p=0,003) \text {. Moderate to severe } \\
\text { acute emesis was lower in the experimental group }(p= \\
0.002) \text {. Moderate to severe delayed nausea was lower } \\
\text { in the experimental group }(p<0.001) \text {. Moderate to } \\
\text { severely delayed emesis was lower in the experimental } \\
\text { group }(p=0.022) \text {. }\end{array}$ \\
\hline $17^{(30)}$ & $\begin{array}{l}2009 / \\
\text { United } \\
\text { States }\end{array}$ & $\begin{array}{l}\text { Double-blind, } \\
\text { randomized, phase II / } \\
\text { III, placebo-controlled } \\
\text { clinical trial, } \mathrm{n}=644 \text { ( } 64 \\
\text { men and } 580 \text { women). } \\
\end{array}$ & $\begin{array}{l}\text { Consumption of } 0.5 \mathrm{~g}, 1 \mathrm{~g} \text {, or } 1.5 \mathrm{~g} \text { of ginger } \\
\text { for } 3 \text { times/day, for } 6 \text { days for } 3 \text { cycles. }\end{array}$ & $\begin{array}{l}\text { Experimental group: reduction of nausea }(p=0.003) \text {. } \\
\text { Acute nausea: } p<0,001 \text {, significant reduction. }\end{array}$ \\
\hline
\end{tabular}




\begin{tabular}{|c|c|c|c|c|}
\hline Reference & \begin{tabular}{|c|} 
Year/ \\
Country
\end{tabular} & $\begin{array}{l}\text { Design/Number of } \\
\text { patients }\end{array}$ & Interventions & Outcomes \\
\hline $18^{(31)}$ & $\begin{array}{l}2009 / \\
\text { United } \\
\text { States }\end{array}$ & $\begin{array}{l}\text { Randomized, double- } \\
\text { blind, placebo- } \\
\text { controlled clinical } \\
\text { trial, } \mathrm{n}=162 \text { ( } 40 \text { men } \\
\text { and } 122 \text { women). }\end{array}$ & $\begin{array}{l}\text { A dose of } 1.2 \mathrm{~g} \text { of ginger, } 4 \text { or } 8 \text { times/day, } \\
\text { for } 3 \text { days, by chemotherapy patients with } \\
\text { emetogenic potential from low to high. }\end{array}$ & $\begin{array}{l}\text { Acute nausea: without aprepitant, } p=0.47 \text {; with aprepitant, } \\
p=0.55 \text {. Delayed nausea: without aprepitant, } p=0.69 ; \text { with } \\
\text { aprepitant, } p=0.01 \text {. Acute emesis: without aprepitant, } p \\
=0.61 ; \text { with aprepitant, } p=0.91 \text {. Delayed emesis: without } \\
\text { aprepitant, } p=0.88 ; \text { with aprepitant, } p=0.77 \text {. In the } \\
\text { experimental group using aprepitant, the intensity of } \\
\text { delayed nausea was higher }(p=0.01 \text { ). At higher dosages of } \\
\text { ginger }(2 g) \text {, there was a higher incidence of delayed nausea } \\
\text { (without aprepitant, } n=17 \text {; with aprepitant, } n=9 \text { ). }\end{array}$ \\
\hline $19^{(32)}$ & 2004/ & $\begin{array}{l}\text { Randomized } \\
\text { controlled clinical } \\
\text { trial, } n=48 \text { women. }\end{array}$ & $\begin{array}{l}\text { Consumption of } 1 \mathrm{~g} \text { of ginger, } 4 \text { times/day, } \\
\text { for } 5 \text { days up to the } 2 \text { nd cycle, by patients } \\
\text { undergoing cisplatin treatment. }\end{array}$ & $\begin{array}{l}\text { Nausea day } 1: p=0.875 . \text { Nausea day } 2: p=0.582 \text {. } \\
\text { Nausea day 3: } p=0.865 \text {. Nausea day } 4: p=0.294 \text {. } \\
\text { Nausea day 5: } p=0.554 \text {. Number of nausea days - } \\
\text { from day } 2 \text { to day 5: } p=0.763 \text {. Control of emesis in } \\
\text { the experimental group: } p=0.754 \text {. Considering a } \\
\text { significance level of } 5 \% \text {, the results were not statistically } \\
\text { significant. }\end{array}$ \\
\hline $20^{(33)}$ & $\begin{array}{l}2003 / \\
\text { India }\end{array}$ & $\begin{array}{l}\text { Randomized, } \\
\text { prospective, crossover, } \\
\text { double-blind study, } \mathrm{n} \\
=50 \text { ( } 11 \text { men and } 39 \\
\text { women). }\end{array}$ & $\begin{array}{l}\text { Consumption of } 1 \mathrm{~g} \text { ginger, } 2 \text { times/day, for } \\
3 \text { days during } 2 \text { cycles, by patients being } \\
\text { treated with combined cyclophosphamide. }\end{array}$ & $\begin{array}{l}\text { Complete nausea control: with ginger (62\%), } \\
\text { metoclopramide (58\%) and ondansetron (86\%). } \\
\text { Complete control of emesis: with ginger (68\%), } \\
\text { metoclopramide (64\%) and ondansetron (86\%). }\end{array}$ \\
\hline $21^{(34)}$ & $\begin{array}{l}2017 / \\
\text { China }\end{array}$ & $\begin{array}{l}\text { Randomized, double- } \\
\text { blind, placebo- } \\
\text { controlled clinical } \\
\text { study, } \mathrm{n}=140 \text { ( } 100 \\
\text { men and } 40 \text { women) }\end{array}$ & $\begin{array}{l}\text { Consumption of } 0.5 \mathrm{~g} \text { ginger, } 2 \text { times/day, } \\
\text { for } 5 \text { days, by patients being treated with } \\
\text { cisplatin. }\end{array}$ & $\begin{array}{l}\text { There was no significant difference between the } \\
\text { experimental and control groups in decreasing the } \\
\text { incidence and intensity of delayed nausea and emesis } \\
\text { ( }>0.05 \text { ). Delayed nausea: experimental group, } 60.6 \% \text {; } \\
\text { control group, } 72.5 \% \text {. Delayed emesis: experimental } \\
\text { group, } 22.5 \% \text {; control group, } 26.1 \% \text {. }\end{array}$ \\
\hline $22^{(35)}$ & $\begin{array}{l}2017 / \\
\text { Iran }\end{array}$ & $\begin{array}{l}\text { Randomized, double- } \\
\text { blind, placebo- } \\
\text { controlled clinical } \\
\text { trial, } \mathrm{n}=80 \text { women. }\end{array}$ & $\begin{array}{l}\text { Consumption of } 1 \mathrm{~g} \text { of ginger, } 4 \text { times/day, } \\
\text { for } 6 \text { days, by chemotherapy patients with } \\
\text { emetogenic potential from low to high. }\end{array}$ & $\begin{array}{l}\text { The incidence of emesis was lower in the experimental } \\
\text { group in the anticipatory }(p=0.04) \text {, acute }(p=0.04) \text { and } \\
\text { delayed }(p=0.003) \text { period. }\end{array}$ \\
\hline $23^{(36)}$ & $\begin{array}{l}2017 / \\
\text { Iran }\end{array}$ & $\begin{array}{l}\text { Randomized, double- } \\
\text { blind, placebo- } \\
\text { controlled crossover } \\
\text { clinical study, } \mathrm{n}= \\
36 \text { ( } 26 \text { men and } 10 \\
\text { women). }\end{array}$ & $\begin{array}{l}\text { Consumption of } 1 \mathrm{~g} \text { ginger, } 4 \text { times/day, for } \\
3 \text { days during } 2 \text { cycles, by patients being } \\
\text { treated with cisplatin. }\end{array}$ & $\begin{array}{l}\text { Control of emesis: day } 1 \text { (experimental group, } 42 \% \text {; } \\
\text { control group } 25 \%) \text {, day } 2 \text { (experimental group, } 25 \% \text {; } \\
\text { control group, } 19 \% \text { ) and day } 3 \text { (experimental group, } \\
19 \% \text {; control group, } 22 \%) \text {. Nausea control: day } 1(p= \\
0.14 \text { ), day } 2(p=0.31 \text { ) and day } 3(p=0.73) \text {, that is, } p> \\
0.05 \text {. }\end{array}$ \\
\hline $24^{(37)}$ & $\begin{array}{l}2008 / \\
\text { United } \\
\text { States }\end{array}$ & $\begin{array}{l}\text { Randomized, clinical } \\
\text { study, } n=28 \text {. }\end{array}$ & No specified dose, 2 times/day, for 3 days. & $\begin{array}{l}\text { There was a reduction in the incidence and intensity of } \\
\text { delayed nausea in the experimental group, in addition } \\
\text { to a decrease in the use of antiemetic drugs, but it was } \\
\text { not statistically significant ( } p>0.05) \text {. }\end{array}$ \\
\hline
\end{tabular}

Note: FLIE: Functional Living Index Emesis.

The articles on the subject began to be published in 2000, and the territorial distribution of these publications was more frequent in Iran and Thailand, with six investigations in each.

According to Chart 1, it is possible to observe that of the 24 intervention studies, 3 were crossover. Of these, one could not evaluate the effectiveness of ginger use. Among the selected articles, 13 are published in both databases: Embase and Pubmed. Regarding the journal, the highest incidence $(n=4)$ of publications on the theme during the period analyzed was in Support Care Cancer, considered Qualis Capes A2 in the nursing area; consecutively, they are Journal of Clinical Oncology, Integrative Cancer Therapies, and Asian Pacific Journal of Cancer Prevention, with an incidence of 2 investigations in each. It is noteworthy that the studies were developed until phase II $(n=9)$, but there was a higher frequency of phase I $(n=15)$ investigations.

In the studies evaluated, it was possible to identify three thematic categories: 1 ) antiemetic action of ginger; 2 ) its influence on the control of nausea and vomiting in the acute phase (in the first 24 hours after chemotherapy); 3 ) its influence on the control of nausea and vomiting in the delayed phase (after 24 hours of administration of antineoplastic agents up to 4 or 5 days later).

Regarding the antiemetic action of ginger, 13 studies observed the action of ginger in nausea ${ }^{(14,16,20-21,23-30,37)}$; of these, $9^{(16,23-30)}$ presented significant results considering significance level of $5 \%$ (p $<0.001^{(16)} ; p=0.002^{(23)} ; p=0.0001^{(24)} ; p=0.04^{(26)} ; p=0.0003^{(27)}, p$ $\left.=0.003^{(29-30)}\right)$. As for emesis, 11 investigations ${ }^{(13,15-16,20-21,23,25,28-29,33,35)}$ described advantages in this therapy, and 6 presented a result with a significance level of less than $5 \%\left(p<0.001^{(16,23)} ; p<0.0001^{(20)}\right.$;

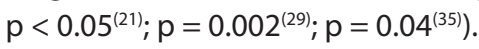

Regarding the influence of this intervention on the control of nausea and vomiting in the acute phase, 11 publications were detected that analyzed nausea in the acute phase ${ }^{(15-16,22-30)}$, among which $8^{(23-30)}$ detected advantages, but only 6 investigations had statistically significant results with $p<5 \%\left(p=0.002^{(23)} ; p=0.0001^{(24)}\right.$; $p=0.04^{(26)} ; p=0.0003^{(27)}, p=0.003^{(29-30)}$. Regarding emesis, 8 studies analyzed the acute stage ${ }^{(14,18,21-22,24,27-28,34)}$; of these, $6^{(19,23,25,28,34)}$ observed the therapeutic effect of ginger, but only 2 had significant results considering significance level of $5 \%\left(p=0.002^{(29)} ; p=0.04^{(35)}\right)$. 
Regarding the influence on the control of nausea and vomiting in the delayed phase, 6 studies $^{(15-16,22-23,28-29)}$ analyzed delayed nausea, 4 observed advantages in the use of ginger ${ }^{(15,22,27-28)}$. Of the investigations, 3 had significant results $\left(p<0.001^{(16,23,29)}\right)$. In the emesis, 6 publications ${ }^{(15,22-23,28-29,35)}$ evaluated the delayed phase, and $4^{(23,28-29,35)}$ described that ginger assisted in the management of this symptom; of these, $3^{(22,28,34)}$ showed significant results ( $p$ $\left.<0.001^{(23)} ; \mathrm{p}=0.022^{(29)} ; \mathrm{p}=0.003^{(35)}\right)$.

Anticipatory nausea was evaluated in 3 investigations ${ }^{(24,27,35)}$, of which 2 demonstrated evidence of the beneficial effect of complementary ginger therapy $\left(p=0.0001^{24)}\right.$ and $\left.p<0.0001^{(27)}\right)$; and, in 1 study, the significance level was higher than $5 \%\left(p=0.04^{(35)}\right)$.

Two investigations verified the antiemetic action of intercycle ginger, in which one observed that the effect was advantageous, and the other did not verify efficacy ${ }^{(16,25)}$.

The scales used to assess the incidence and intensity of symptoms were varied; of these, stood out: Common Terminology Criteria for Adverse Events (CTCAE) ${ }^{(16-17,23)}$, Rhodes Inventory of Nausea, Vomiting and Retching $(\text { INVR })^{(15,22,26)}$ and Edmonton Scale ${ }^{(16,28-29)}$.

Adverse manifestations were observed in isolation in six studies, which comprised: constipation and reflux ${ }^{(15,22)}$, heartburn ${ }^{(26-27,35)}$, headache ${ }^{(26)}$, vertigo ${ }^{(26)}$, skin rash ${ }^{(27,36)}$, pruritus ${ }^{(36)}$, intestinal discomfort $^{(36)}$ - which may also be related to chemotherapy.

The samples from the studies were predominantly composed of female people, and the mean age group showed variation between 41 and 59 years, and only 1 study ${ }^{(28)}$ analyzed children and young people between 9 and 21 years old. A total of 16 studies with a sample of fewer than 100 patients were published.

The type of cancer was addressed in 18 studies, of which $12^{(15-}$ 17,19-20,22,24,26-27,30,32,35) analyzed the breast; and 4, the lung ${ }^{(18,27,30,34,36)}$. The pathology stage was addressed only in 4 studies $^{(14,16-18)}$, and in 2 of them, phase II presented a higher occurrence ${ }^{(14,17)}$.

Seventeen studies exposed the chemotherapy protocol investigated, of which $6^{(15-16,22-23,31,35)}$ evaluated those who had emetogenic potential from moderate to high but did not mention the names of the drugs. Among the investigations that specified the treatment, the platinum-based protocol was more recurrent, which seven investigations mentioned ${ }^{(13,17,24,28,31,33,35)}$, followed by cyclophosphamide ${ }^{(17,19,26,33)}$.

Among the exclusion criteria related to the use of concomitant medications that could interfere with the results, eight studies considered the use of anticoagulants ${ }^{(18,20,25,27,31,34-36)}$; four, warfa$\operatorname{rin}^{(16,20,35-36)}$, and three, aspirin ${ }^{(20,35-36)}$. This consideration is due to ginger having anticoagulant action.

Five studies evaluated the use of the aprepitant compound associated with ginger ${ }^{(15,22,28,31,34)}$, of which two reported that the combination interfered with the improvement of symptoms ${ }^{(31,34)}$.

Within category 1, dosage and posology were also considered. From this perspective, it was possible to observe that 14 studies presented the dosage of $1 \mathrm{~g}$ of ginger per day, and the number of capsules diversified according to the number of milligrams of each tablet, the more common consumption was four times (10 articles) or two times ( 9 publications) per day. Most of the investigations reported that ginger powder at a dose of $1 \mathrm{~g} /$ day softened the clinical nausea of various causes ${ }^{(14,19-20,24,27,29-30,32-33,35)}$. The most analyzed periods of use were three days (8 investigations) and five days ( 5 studies). Of these publications, four reported the onset of ginger use three days before chemotherapy; one observed it five days earlier, and the others on the day of treatment. All investigations in which complementary therapy began in the three and five days before chemotherapy, demonstrated the benefits of ginger.

Seven studies reported the number of active components of the capsule, which specified the concentration of gingerol in an interval of $1.4 \%$ to $5 \%$, and $5 \%$ was the most frequent composition, described in 4 articles. Regarding shogaol, four investigations used it in the ratio between 0.00112 and 0.0085 , and the dosage 0.00092 repeatedly occurred in 2 articles. Thus, we observe the divergence in the studies in the capsule formulation, so that it is not possible to compare the results concerning the bioavailability of this complementary therapy. Only four studies have described performing a validation test on the content of the capsule's active components; of these, three specified performing the test by high-efficiency liquid chromatography ${ }^{(15,22,26,31)}$.

\section{DISCUSSION}

We did not include the review studies in this manuscript, however, in the literature, it is possible to observe that, in the first investigation with this type of design, published in 2000, concluded that the analyzed clinical data were insufficient to obtain definite evidence. However, it highlighted that ginger is believed to be a potential natural antiemetic drug ${ }^{(38)}$. This result is consistent with the results of the first published clinical trials. New reviews were carried out only in 2012, that is, after more than a decade, and the results were contradictory, and it is not possible to prove statistically significant benefits from the action of ginger ${ }^{(39-42)}$. However, from 2013, the benefits of ginger began to be confirmed; and, from 2015 to 2018, published reviews observed the advantages of this integrative therapy, when assessing different methodologies ${ }^{(43-47)}$.

In Brazil, since 2016, there is the National Policy and Program for Medicinal Plants and Herbal Medicines, which presents guidelines for their management, production, cultivation, commercialization, monitoring, communication strategies, human resources, qualification, validations, the definition of concepts, among others. Thus, these guidelines enable the production of equipment and fundamental technologies for quality assurance and control, promotion of the production system, and the creation of methods for monitoring and analyzing technology inclusion ${ }^{(48)}$.

In this context, the World Health Organization (WHO) published guidelines for monitoring and pharmacovigilance of medicinal plants in 2003, in which it recommends the inclusion of medicinal plants, traditional and complementary medicine; defines concepts; addresses medication errors, efficacy, excess and drug combinations and interactions; recognizes adverse reactions and prevention methods; estimates risks and event prevention. Such material intends to support member countries in qualifying in pharmacovigilance; insert plants in the International Pharmacovigilance System; standardize terms and classifications; encourage and consolidate international exchanges of information and safety instructions between centers; and enable security. These types of policies prevent the intentional or accidental introduction of prohibited or restricted components, the modification 
of constituents, contamination with toxic substances, and the inadequate information of the declared content when considering the actual content ${ }^{(49-50)}$.

However, it is possible to observe that, in the literature, there is no disclosure of data regarding formulation, extraction methods, quality control, and validation, which can interfere in the bioavailability of the active components derived from ginger. Only four studies cited the validation test for the content of the active components of the ${ }^{(15,22,26,31)}$ capsule, and this lack of quality control may interfere with the evidence.

In this context, the antiemetic and anti-inflammatory action of ginger is related to its bioactive components, including gingerol and shogaol, which can manage nausea and emesis, body temperature, cough, inflammation and systemic blood pressure $^{(14)}$. Thus, it reinforces the need to standardize the dose of the bioactive components of ginger in the composition of the capsules concomitantly with quality control.

In such a scenario, the effectiveness of ginger in a capsule for reduction of acute and anticipatory nausea at a dosage of $1 \mathrm{~g}$ / day was demonstrated, with the protocol starting three days before chemotherapy administration until the following three days, associated with antiemetic treatment ${ }^{(24)}$. Another article with a similar methodology presented the same positive result concerning acute and anticipatory nausea, and the early use of ginger was related to the induction of 5-HT3 binding with consequent stimulation of detoxification enzymes that neutralize oxidative damage to the tissues causing these gastrointestinal symptoms. Besides, in this clinical trial, it was observed that lower doses of ginger are more beneficial than higher doses, as these can saturate the base of receptors of the mechanism of action ${ }^{(27)}$. Likewise, a study that analyzed the dosages of $0.5 \mathrm{~g}, 1 \mathrm{~g}$, and $1.5 \mathrm{~g}$ showed greater effectiveness of the two smaller compositions ${ }^{(30)}$.

Additionally, ginger has demonstrated its antiemetic action as a complementary therapy to the drugs ondansetron (8mg) and dexamethasone (12 or $8 \mathrm{mg}$ according to emetogenic potential), by the intravenous route, on the day of chemotherapy application. Also, from the 2nd to the 4th day, orally, when combined with metoclopramide $10 \mathrm{mg}$ three times/day as a standard treatment for patients with solid tumors ${ }^{(15)}$ as well as combined with palonosetron and dexamethasone ${ }^{(28)}$. However, two studies could not prove the effectiveness of ginger in breast cancer patients undergoing chemotherapy with high emetogenic potential, when combined with ondansetron $(8 \mathrm{mg}$ ) and metoclopramide (10 mg) as a standard protocol which include, as needed, rescue drugs (ondansetron domperidone or metoclopramide), in the days after chemotherapy ${ }^{(17,23)}$. It is concluded that the antiemetic action of ginger was observed when used concomitantly with conventional preventive treatment both on the day of chemotherapy administration and on the following 4 days.

One publication compared the effect of ginger to $40 \mathrm{mg} /$ day of metoclopramide in the delayed period (2nd to 5th day after chemotherapy). However, its effectiveness was not superior to conventional therapy with granisetron and dexamethasone in patients with breast cancer undergoing chemotherapy protocols with moderate to high emetogenic potential ${ }^{(26)}$. A study that analyzed patients undergoing cisplatin treatment ${ }^{(32)}$ made a similar comparison, and also another, which evaluated participants in combined treatment with cyclophosphamide. However, this one observed that ondansetron was more effective than ginger and metoclopramide ${ }^{(33)}$.

The combined therapy of ginger extract in a dosage of $2 \mathrm{~g} /$ day with aprepitant caused an increase in the intensity of nausea and delayed vomiting ${ }^{(31)}$. However, there is a divergence in the result when using the dosage $0.5 \mathrm{~g} / \mathrm{day}$, in which there were no significant differences in the incidence and severity of these symptoms ${ }^{(34)}$. As previously mentioned, we emphasized that the action of ginger was more effective in smaller doses. There are doubts regarding the influence of ginger combined with aprepitant in reducing gastrointestinal absorption and amplifying its motility with a consequent decrease in gastric emptying time and the antiemetic effectiveness of the drug ${ }^{(31)}$, so there is a need for further studies to confirm this statement.

The divergence of results regarding the combined ginger therapy with the standard antiemetic protocol may be related to the different methodologies employed.

Regarding the characteristics of the samples, there is evidence that women are more likely to have symptoms of nausea and vomiting induced by chemotherapy than men ${ }^{(40)}$. Thus, sex may have contributed to the patient's reaction to ginger therapy by decreasing the intensity of the symptom and, thus, contributing to the effectiveness of antiemetic therapies.

\section{Study Limitations}

There are still many controversial studies regarding the benefits of ginger. This fact is due to the scarcity of supporting evidence because of the small number of investigations, as well as the lack of standardization of the sample, composition, method, and period of use.

\section{Contributions to the field}

Nausea and emesis are significant symptoms in patients undergoing chemotherapy, because, despite the various existing therapies, they continue to be reactions of high incidence. Therefore, the inclusion of complementary evidence-based therapy associated with traditional pharmacological treatment can assist in managing the incidence and intensity of these adversities that affect the patient's quality of life and routine. Although the results on the benefits of ginger for the management of gastrointestinal adverse reactions induced by chemotherapy are conflicting, the present study allowed the integration of knowledge on the subject; the identification of varied theoretical and methodological approaches; and the detection of the limitations of investigations that may interfere with the evidence. Therefore, this integrative review can contribute to the development of future research.

\section{FINAL CONSIDERATIONS}

In this study, it was possible to observe that the results on the benefits of ginger for the management of nausea and emesis in the acute and delayed stages are contradictory. The difficulty found for the convergence of the evidence was related to the heterogeneity of the samples, the diversity of the antiemetic 
treatment used, the lack of standardization in the dosage and formulation of the active components. There is a need for future studies to understand better and standardize its use to assess its bioavailability in the body. This complementary therapy is inexpensive, easy to access, and some studies have demonstrated its effectiveness in controlling nausea and vomiting induced by chemotherapy. However, other studies with standardized methodology will contribute to a better definition of care protocols.

\section{REFERENCES}

1. Instituto Nacional do Câncer (Br). Estimativa 2018: incidência do câncer no Brasil [Internet]. Rio de Janeiro: INCA; 2018 [cited 2018 Aug 01]. Available from: http://www.inca.gov.br/estimativa/2018/sintese-de-resultados-comentarios.asp

2. Bossi P, Cortinovis D, Rocca MC, Roila F, Seminara P, Fabi A, et al. Searching for evidence to support the use of ginger in the prevention of chemotherapy-induced nausea and vomiting. J Altern Complement Med. 2016;22(6):486-8. doi: 10.1089/acm.2015.0315

3. Gansler T, Kaw C, Crammer C, Smith T. A population-based study of prevalence of complementary methods use by cancer survivors: a report from the American Cancer Society's studies of cancer survivors. Cancer. 2008;113(5):1048-57. doi: 10.1002/cncr.23659

4. Frenkel M, Sierpina V. The use of dietary supplements in oncology. Curr Oncol Rep. 2014;16(11):411. doi: 10.1007/s11912-014-0411-3

5. Lyman GH, Greenlee H, Bohlke K, Bao T, DeMichele AM, Deng GE, et al. Integrative therapies during and after breast cancer treatment: ASCO endorsement of the SIO clinical practice guideline. J Clin Oncol. 2011;36(25):2647-55. doi: 10.1200/JCO.2018.79.2721

6. Boon HS, Olatunde F, Zick SM. Trends in complementary/alternative medicine use by breast cancer survivors: Comparing survey data from 1998 and 2005. BMC Womens Health. 2007;7:4. doi: 10.1186/1472-6874-7-4

7. Link AR, Gammon MD, Jacobson JS, Abrahamson P, Bradshaw PT, Terry MB, et al. Use of self-care and practitioner-based forms of complementary and alternative medicine before and after a diagnosis of breast cancer. Evid Based Complement Alternat Med. 2013;2013:301549. doi: 10.1155/2013/301549

8. Mendes KDS, Silveira RCCP, Galvão CM. Revisão integrativa: método de pesquisa para a incorporação de evidências na saúde e na enfermagem. Texto Contexto Enferm. 2008;17(4):758-64. doi: 10.1590/S0104-07072008000400018

9. Delgado GL, Gazzi LAP, Pondé NF, Beraldo FB, Soares WGP, Pires LA. Náuseas e vômitos antecipatórios: Pontos Fundamentais. Rev Bras Oncol Clín [Internet]. 2006[cited 2018 Aug 01];3(8):7-11. Available from: https://www.sboc.org.br/sboc-site/revista-sboc/pdfs/8/artigo1.pdf

10. Klopper R, Lubbe S, Rugbeer H. The matrix method of literature review. Alternation [Internet]. 2007 [cited 2018 Aug 01];14(1):262-76. Available from: http://alternation.ukzn.ac.za/Files/docs/14.1/12\%20Klopper\%20.pdf

11. Ganong LH. Integrative reviews of nursing research. Res Nurs Health [Internet]. 2007 [cited 2018 Aug 1];10(1):1-11. Available from: https:// www.ncbi.nlm.nih.gov/pubmed/3644366

12. Moher D, Liberati A, Tetzlaff J, Altman DG, The PRISMA Group. Preferred Reporting Items for Systematic Reviews and Meta-Analyses: The PRISMA Statement [Internet]. 2018 [cited 2018 Aug 1]. Available from: http://www.equator-network.org/reporting-guidelines/prisma/

13. Santos CMC, Pimenta CAM, Nobre MRC. A estratégia PICO para a construção da pergunta de pesquisa e busca de evidências. Rev Latino-Am Enfermagem. 2007;15(3). doi: 10.1590/S0104-11692007000300023

14. Shokri F, Gharebaghi PM, Esfahani A, Sayyah-Melli M, Shobeiri MJ, Ouladsahebmadarek E, et al. Comparison of the complications of platinum-based adjuvant chemotherapy with and without ginger in a pilot study on ovarian cancer patients. Int J Womens Health Reprod Sci. 2017;5(4):324-31. doi: 10.15296/ijwhr.2017.55

15. Marx W, McCarthy AL, Ried K, McKavanagh D, Vitetta L, Sali A, et al. The effect of a standardized ginger extract on chemotherapy-induced nausea-related quality of life in patients undergoing moderately or highly emetogenic chemotherapy: a double blind, randomized, placebo-controlled trial. Nutrients. 2017;9(8):867. doi: 10.3390/nu9080867

16. Konmun J, Danwilai K, Ngamphaiboon N, Sripanidkulchai B, Sookprasert A, Subongkot S. A phase II randomized double-blind placebocontrolled study of 6-gingerol as an anti-emetic in solid tumor patients receiving moderately to highly emetogenic chemotherapy. Med Oncol. 2017;34(4):69. doi: 10.1007/s12032-017-0931-4

17. Thamlikitkul L, Srimuninnimit V, Akewanlop C, Ithimakin S, Techawathanawanna S, Korphaisarn K, et al. Efficacy of ginger for prophylaxis of chemotherapy-induced nausea and vomiting in breast cancer patients receiving adriamycin-cyclophosphamide regimen: a randomized, double-blind, placebo-controlled, crossover study. Support Care Cancer. 2017;25(2):459-64.doi: 10.1007/s00520-016-3423-8

18. Bossi P, Cortinovis D, Fatigoni S, Rocca MC, Fabi A, Seminara P, et al. A randomized, double-blind, placebo-controlled, multicenter study of a ginger extract in the management of chemotherapy-induced nausea and vomiting (CINV) in patients receiving high-dose cisplatin. Ann Oncol. 2017;28(10):2547-51. doi: 10.1093/annonc/mdx315

19. Ansari M, Porouhan $P$, Mohammadianpanah M, Omidvari S, Mosalaei A, Ahmadloo N, et al. Efficacy of ginger in control of chemotherapy induced nausea and vomiting in breast cancer patients receiving doxorubicin-based chemotherapy. Asian Pac J Cancer Prev. 2016;17(8):3877-80. doi: 10.14456/apjcp.2016.186/APJCP.2016.17.8.3877

20. Sanaati F, Najafi S, Kashaninia Z, Sadeghi M. Effect of ginger and chamomile on nausea and vomiting caused by chemotherapy in iranian women with breast cancer. Asian Pac J Cancer Prev. 2016;17(8):4125-9. doi: 10.14456/apjcp.2016.225/APJCP.2016.17.8.4125 
21. Arslan M, Ozdemir L. Oral intake of ginger for chemotherapy-induced nausea and vomiting among women with breast cancer. Clin J Oncol Nurs. 2015;19(5):E92-7. doi: 10.1188/15.CJON.E92-E97

22. Marx W, McCarthy A, Vitetta L, Ried K, McKavanagh D, Thomson D, et al. Standardized ginger extract improves quality of life associated with chemotherapy-induced nausea and vomiting. Asia Pac J Clin Oncol. 2016;12(S5):87-87. doi: 10.1111/ajco.12630

23. Konmun J, Danwilai K, Ngamphaiboon N, Sookprasert A, Sirachainan E, Subongkot S. A phase II randomized, double-blind placebocontrolled trial of an antiemetic, 6-gingerol in solid tumor patients receiving moderately to highly emetogenic adjuvant chemotherapy. J Clin Oncol. 2014;32(15 Suppl):9647. doi: 10.1200/jco.2014.32.15_suppl.9647

24. Ebrahimi SM, Parsa-Yekta Z, Nikbakht-Nasrabadi A, Hosseini SM, Sedighi S, Salehi-Surmaghi MH. Ginger effects on control of chemotherapy induced nausea and vomiting. Tehran Univ Med J [Internet]. 2013 [cited 2018 Aug 1];71(6):395-403. Available from: http://tumj.tums.ac.ir/ browse.php?a_id=5429\&sid=1\&slc_lang=en

25. Montazeri AS, Raei M, Ghanbari A, Dadgari A, Montazeri AS, Hamidzadeh A. Effect of herbal therapy to intensity chemotherapy-induced nausea and vomiting in cancer patients. Iran Red Crescent Med J. 2013;15(2):101-106. DOI:10.5812/ircmj.4392

26. Panahi Y, Saadat A, Sahebkar A, Hashemian F, Taghikhani M, Abolhasani E. Effect of ginger on acute and delayed chemotherapy-induced nausea and vomiting: a pilot, randomized, open-label clinical trial. Integr Cancer Ther. 2012;11(3):204-11. doi: 10.1177/1534735411433201

27. Ryan JL, Heckler CE, Roscoe JA, Dakhil SR, Kirshner J, Flynn PJ, et al. Ginger (Zingiber officinale) reduces acute chemotherapy-induced nausea: a URCC CCOP study of 576 patients. Support Care Cancer. 2012;20(7):1479-89. doi:10.1007/s00520-011-1236-3

28. Chandra A, Martin JP. Antiemetic effect of encapsulated ginger powder as na add-on therapy for chemotherapy - induced nausea and vomiting. A study from India. Support Care Cancer. 2011;19(Suppl 2):S347. doi: 10.1007/s00520-011-1184-y

29. Pillai AK, Sharma KK, Gupta YK, Bakhshi S. Anti-emetic effect of ginger powder versus placebo as an add-on therapy in children and young adults receiving high emetogenic chemotherapy. Pediatr Blood Cancer. 2011;56(2):234-8. doi: 10.1002/pbc.22778

30. Ryan JL, Heckler C, Dakhil SR, Kirshner J, Flynn PJ, Hickok JT, et al. Ginger for chemotherapy-related nausea in cancer patients: A URCC CCOP randomized, double-blind, placebo-controlled clinical trial of 644 cancer patients. J Clin Oncol. 2009;27(15Suppl):9511. doi: 10.1200/ jco.2009.27.15_suppl.9511

31. Zick SM, Ruffin MT, Lee J, Normolle DP, Siden R, Alrawi S, et al. Phase II trial of encapsulated ginger as a treatment for chemotherapy-induced nausea and vomiting. Support Care Cancer. 2009;17(5):563-72. doi: 10.1007/s00520-008-0528-8

32. Manusirivithaya S, Sripramote M, Tangjitgamol S, Sheanakul C, Leelahakorn S, Thavaramara T, et al. Antiemetic effect of ginger in gynecologic oncology patients receiving cisplatin. Int J Gynecol Cancer. 2004;14(6):1063-9. doi: 10.1111/j.1048-891X.2004.14603.X

33. Sontakke S, Thawani V, Naik MS. Ginger as an antiemetic in nausea and vomiting induced by chemotherapy: a randomized, cross-over, double blind study. Indian J Pharmacol [Internet]. 2003 [cited 2018 Aug 1];35:32-6. Available from: medind.nic.in/ibi/t03/i1/ibit03i1p32.pdf

34. Li X, Qin Y, Liu W, Zhou XY, Li YN, Wang LY. Efficacy of ginger in ameliorating acute and delayed chemotherapy-induced nausea and vomiting among patients with lung cancer receiving cisplatin-based regimens: a randomized controlled trial. Integr Cancer Ther. 2018;17(3):747-54. doi: $10.1177 / 1534735417753541$

35. Yekta ZP, Ebrahimi SM, Hosseini M, Nasrabadi AN, Sedighi S, Surmaghi MH, et al. Ginger as a miracle against chemotherapy-induced vomiting. Iran J Nurs Midwifery Res [Internet]. 2012 [cited 2018 Aug 5];17(5):325-9. Available from: https://www.ncbi.nlm.nih.gov/pmc/ articles/PMC3703071/

36. Fahimi F, Khodadad K, Amini S, Naghibi F, Salamzadeh J, Baniasadi S. Evaluating the effect of Zingiber officinalis on nausea and vomiting in patients receiving cisplatin based regimens. Iran J Pharm Res [Internet]. 2011 [cited 2018 Aug 5];10(2):379-84. Available from: https://www. ncbi.nlm.nih.gov/pmc/articles/PMC3828901/

37. Levine ME, Gillis MG, Koch SY, Voss AC, Stern RM, Koch KL. Protein and ginger for the treatment of chemotherapy-induced delayed nausea. J Altern Complement Med. 2008;14(5):545-51. doi: 10.1089/acm.2007.0817

38. Ernst E, Pittler MH. Efficacy of ginger for nausea and vomiting: a systematic review of randomized clinical trials. Br J Anaesth. 2000;84(3):36771. doi: 10.1093/oxfordjournals.bja.a013442

39. Lee J, Oh H. Ginger as an antiemetic modality for chemotherapy-induced nausea and vomiting: a systematic review and meta-analysis. Oncol Nurs Forum. 2013;40(2):163-70. doi: 10.1188/13.ONF.163-170

40. Marx WM, Teleni L, McCarthy AL, Vittetta L, McKavanagh D, Thomson D, et al. Is ginger supplementation effective in ameliorating chemotherapy-induced nausea and vomiting? Cosa 39Th Annual Scientific Meeting and IPOS 14Th World Congress of PsychoOncology. Asia Pac J Clin Oncol. 2012 [cited 2018 Aug 5];8(Suppl-3):323. Available from: https://research.bond.edu.au/en/publications/ is-ginger-supplementation-effective-in-ameliorating-chemotherapy-

41. Lee J, Oh H. Ginger for chemotherapy-induced nausea and vomiting (CINV) control? Current evidence of ginger as an antiemetic modality for CINV management: a systematic review. Support Care Cancer. 2012;20(Suppl 1):S79. doi: 10.1007/s00520-012-1479-7

42. Haniadka R, Rajeev AG, Palatty PL, Arora R, Baliga MS. Zingiber officinale (ginger) as an anti-emetic in cancer chemotherapy: a review. J Altern Complement Med. 2012;18(5):440-4. doi: 10.1089/acm.2010.0737

43. Marx W, Ried K, McCarthy AL, Vitetta L, Sali A, McKavanagh D, et al. Ginger-Mechanism of action in chemotherapy-induced nausea and vomiting: a review. Crit Rev Food Sci Nutr. 2017;57(1):141-6. doi: 10.1080/10408398.2013.865590 
44. Lete I, Allué J. The effectiveness of ginger in the prevention of nausea and vomiting during pregnancy and chemotherapy. Integr Med Insights. 2016;11:11-17. doi: 10.4137/IMI.S36273

45. Marx W, Kiss N, Isenring L. Is ginger beneficial for nausea and vomiting? An update of the literature. Curr Opin Support Palliat Care. 2015;9(2):189-95. doi: 10.1097/SPC.0000000000000135

46. Giacosa A, Morazzoni P, Bombardelli E, Riva A, Bianchi Porro G, Rondanelli M. Can nausea and vomiting be treated with ginger extract? Eur Rev Med Pharmacol Sci [Internet]. 2015 [cited 2018 Aug 01];19(7):1291-6. Available from: https://www.ncbi.nlm.nih.gov/pubmed/25912592

47. Crichton M, Marshall S, Marx W, Isenring E. Efficacy of ginger (zingiber officinale) in ameliorating chemotherapy-induced nausea and vomiting and chemotherapy-related outcomes: a systematic literature review update and meta-analysis. Nutr Diet. 2018;75(S1):42. doi: $10.1111 / 1747-0080.12426$

48. Corrêa Jr CC, Scheffer MC. Boas Práticas Agrícolas (BPA) de plantas medicinais, aromáticas e condimentares [Internet]. Instituto Paranaense de Assistência Técnica e Extensão Rural - EMATER. Curitiba. 2013[cited 2018 Aug 01]. Available from: http://portalarquivos.saude.gov.br/ images/pdf/2015/agosto/28/bpa-plantas-medicinais-aromaticas-condimentares.pdf

49. World Health Organization. Guidelines on good agricultural and collection practices (GACP) for Medicinal plants [Internet]. Geneva: WHO; 2003[cited 2018 Aug 01]. Available from https://apps.who.int/medicinedocs/en/d/Js4928e/

50. Silveira PF, Bandeira MAM, Arrais PSD. Farmacovigilância e reações adversas às plantas medicinais e fitoterápicos: uma realidade. Rev Bras Farmacogn. 2008;18(4). doi: 10.1590/S0102-695X2008000400021 